Biological and Clinical Sciences Research Journal

ISSN: 2708-2261

www.bcsrj.com

DOI: https://doi.org/10.54112/bcsrj.v2020i1.47

Biol. Clin. Sci. Res. J., Volume, 2020: 47

Mini Review Article

\title{
TOXIC EFFECTS OF LEAD ON FISH AND HUMAN
}

\author{
ISHAQUE $A^{1}$, ISHAQUE S, ARIF $A^{1}$, ABBAS HG ${ }^{2}$ \\ ${ }^{I}$ Institute of Molecular Biology and Biotechnology, The University of Lahore, Lahore, Pakistan \\ ${ }^{2}$ Department of Biotechnology, Kinnaird College for Women, Lahore, Pakistan \\ ${ }^{3}$ Cotton Research Institute, Ayub Agricultural Research Institute Faisalabad, Pakistan \\ Corresponding author: asmaishaque137@gmail.com
}

(Received, $07^{\text {th }}$ July 2020, Revised $25^{\text {th }}$ December 2020, Published $28^{\text {th }}$ December 2020)

\begin{abstract}
Bioaccumulation is a characteristic aspect in toxicity caused by Pb exposure. Toxic effects are induced in fish due to Pb exposure effecting its biochemical and physiological functions. Exposure pathway (dietary and waterborne), environmental factors (salt-water or fresh water) and Pb binding capacity with protein, SH and sulfur group decide accumulation pattern of Pb exposure. Activation of antioxidant responses like TBARS, GSH, GST, $C A T$ and SOD occurs in fish for its protection in response to the oxidative stresses induced in fish due to $\mathrm{Pb}$ accumulation. Disruption of neurotransmitter function also occurs due to Pb accumulation which causes neurotoxicity in fish. Pb interaction also disturbs immune system responses. In fish, various systems are affected due to $\mathrm{Pb}$ toxic exposure which can be used as an indicator of toxicity in aquatic environment.
\end{abstract}

Keywords: Lead, heavy metal, toxicity, antioxidant, biochemical, physiological

\section{Lead}

Earth crust contains lead in trace amount that is generally found in plant, rocks, air, water and soil (Cheng and $\mathrm{Hu}, 2010)$. Although aquatic habitats are omnipresent with lead but anthropogenic activities that include smelting, mining, manufacturing of paints, cement and batteries raise its level (Chain, 2010; Flegal, 1986; Kim and Kang, 2016b). Lead combines (naturally) with other elements to form lead compounds and in environment it occurs predominantly in inorganic form (Pb II, TEL, trimethyl lead), however organic states found which was reported record toxic in the form of TtEL (Chang et al., 2007; Chen et al., 2014; Flegal, 1986; Lee and Jiang, 2005). Pb bio- magnification does not occur in food chain. Accumulation of $\mathrm{pb}$ in older organisms causes the increase in body burden as they are stored on bony tissues.

\section{Lead toxicity in human}

Lead compound mainly target reproductive (Apostoli et al., 1998; Assennato et al., 1987; Braunstein et al., 1978; Lerda, 1992; Telisman et al., 2000), digestive (Sakai, 2000), skeletal (Oflaherty, 1995), peripheral and central NS (Campara et al., 1984; Hogstedt et al., 1983; Lead, 1995; Mantere et al., 1984), immunological system (Coscia et al., 1987; Ewers et al., 1982; Gidlow, 2015) and kidney (Ehrlich et al., 1998; Gerhardsson et al., 1992; Goyer, 1989; Lead,
1995; Loghman-Adham, 1997). While chronic $\mathrm{Pb}$ exposure leads cardiotoxicity (Evis et al., 1987; Lai et al., 1991), neurotoxicity, nephrotoxicity (KhalilManesh et al., 1993), carcinogenicity (IARC, 2006) and genotoxicity (IARC, 2006) in humans. Ingesting $\mathrm{Pb}$ contaminated sea food causes acute toxicity in kidney and brain. $\mathrm{Pb}$ gastrointestinal absorption is dependent on iron, calcium status of the human body as well on the age that is kids are more vulnerable as they absorb more lead. Lead is accumulated in bones, blood and soft tissue after its absorbance into the blood steam. Lead has high affinity with protein due to its stable complex formation with sulfur and oxygen atom of protein structure (Verstraeten et al., 2008). Ferrochelatase (involve in the catalyzation of porphyrin ring by iron), delta-aminolevulinic acid synthase (synthesize porphobilinogen (PBG) which is important for biosynthesis of hemeproteins) and delta-aminolevulinic acid dehydratase are three vital human heme enzymes which are inhibited due to $\mathrm{Pb}$ accumulation. This inhibition causes hemoglobin level to drop and inhibit the metabolism of cytochrome P450- dependent phase (Alvares et al., 1976; Bernard and Lauwerys, 1984; Goering, 1993; Jaishankar et al., 2014; Philip and Gerson, 1994; Ponka, 1999).

Lead toxicity in fish

Inhibition of inocytes basolateral transport mechanism in the epithelium of gills causes

[Citation: Ishaque, A., Ishaque, S., Malik, A., Abbas, H.G. (2020). Toxic effects of lead on fish and human. Biol. Clin. Sci. Res. J., 2020: 47. doi: https://doi.org/10.54112/bcsrj.v2020i1.47] 
hypocalcemia in fish due to lead accumulation. It is because of lead high affinity with $\mathrm{Ca}^{2+}$ ATPase, $\mathrm{Na}^{2+} \mathrm{K}^{+}$ATPase and $\mathrm{Na}^{+} \mathrm{Ca}^{2+}$ exchanger which disturb ion regulation and electrochemical gradient in cells (Verstraeten et al., 2008). Hence, bioaccumulation even at small concentration due to $\mathrm{Pb}$ exposure can prove fatal to aquatic animals (Kim and Kang, 2015b). Lead poisoning and oxidative stress can be caused by the imbalance between antioxidants and pro oxidants (Kim and Kang, 2017b). In fish, persuaded intensified antioxidant response due to lead exposure can produce ROS (reactive oxygen species). $\mathrm{Pb}$ has high affinity for RBCs which result in toxic effects on function and structure of cellular membranes and cause high oxidative stress in fish (Gurer and Ercal, 2000). Immunological parameter including piscine immune system is being affected due to the lead stress (Kim and Kang, 2016c). In animals, $\mathrm{Pb}$ acts as a critical immune toxicant (Paul et al., 2014). Lead has diverse stroke exposure and toxic effects; thus, an inclusive research is needed to define the $\mathrm{Pb}$ exposure in fish.

\section{Bioaccumulation}

Metals show its toxic effects in fish when they are taken up by the body and is bioaccumulated followed by the detoxification mechanism, metabolic and excretory process (Eroglu et al., 2015). In fish metal contamination occur either through gastrointestinal track when they intake contaminated food or through gill if metal ions are present in water. Liver as metal excretory system play its role in binding of $\mathrm{Pb}$ to steroid in bile and then out of the body through feces (Sures et al., 2003; Zhai et al., 2017). Circulatory system is responsible for circulating the ingested metal to rest of body (Zhai et al., 2017), where metals either stored in tissues, or is lethal to target organ or is excreted outside the body via gills and kidney (Kim and Kang, 2014, 2015a, 2016a). Dietary exposure of $\mathrm{Pb}$ to juvenile rockfish, Sebastes schlegelii, show accumulation of $\mathrm{Pb}$ in its various tissue include gills, intestine, liver and spleen. Hwang et al. (2016) also testified the similar trend of $\mathrm{Pb}$ accumulation in Platichthys stellatus who was experienced to dietary $\mathrm{Pb}$.

$\mathrm{Ca}^{2+}, \mathrm{Na}^{+}$and $\mathrm{K}^{+}$ionic homeostasis is disturbed when body have chronic exposure against lead (Grosell et al., 2006). Antagonistic actions of $\mathrm{Ca}^{2+}$ and $\mathrm{Pb}^{2+}$ lessen $\mathrm{Pb}$ toxicity in fish body because $\mathrm{Ca} 2+$ stick to dissolved ambient $\mathrm{Pb}$ and help to lower $\mathrm{Pb}$ accumulation in body (Alves et al., 2006; Audesirk, 1993; Rogers et al., 2003). There are two pathways by which metal can accumulate in the body i.e. dietary or waterborne metal exposure. Water borne exposure result in the accumulation of metal in gills because during osmoregulation and respiration, gills come in direct contact with metal (Alves et al., 2006; Rogers et al., 2003). While dietary exposure accumulates high metal concentration in intestinal tissues (Alves et al., 2006; Castro-González and Méndez-Armenta, 2008). Water borne exposure has high risk of $\mathrm{Pb}$ accumulation in the gills as compared to the dietary intake (Dural et al., 2007; Farkas et al., 2003; Grosell et al., 2006; Kalay et al., 1999; Souid et al., 2015). Metals bound to the subcellular fractions of prey when the gut is exposed to dietary metal pathway makes the microbiota to reduce however when exposed to water the bioavailability is 20-60 times more (Alsop et al., 2016). Environmental differences also play its role in the bioaccumulation of the metal i.e. sea water and fresh water. To avoid from dehydration under high osmotic pressure condition, marine fish drink a lot of water that cause prominent metal accumulation in the intestinal tissue. While in the case of fresh water specie, gills are at high risk of metal accumulation because fish under low osmotic pressure environment actively transport ions outside the body through inocytes in the gill (Kim and Kang, 2014). Metabolic active organs have been reported to be on a high risk for metal accumulation. Acute or chronic $\mathrm{Pb}$ effects the target organs liver and kidney, due to their role in detoxification and elimination of toxic element outside the body (Javed, 2012; Patra et al., 2001; Vinodhini and Narayanan, 2008; Zhai et al., 2017). Spleen is also accumulated with $\mathrm{Pb}$ because it functions in the removal of xenobiotic from blood (Kim and Kang, 2015b; Somero et al., 1977). Gills and intestine accumulate $\mathrm{Pb}$ directly from water or food (Kim and Kang, 2017a). Pb accumulation has been reported lowest in the fish muscles and it is important indicator of food safety because fish muscles are directly accumulated by the humans (AlBalawi et al., 2013; Dural et al., 2007; Farkas et al., 2003; Sures and Siddall, 1999; Zhai et al., 2017).

\section{Neurotoxicity}

$\mathrm{Pb}$ is neuro toxicant whose exposure directly affect CNS of fish that results in the neurotoxicity, cognitive and behavioral dysfunction (Hsu and Guo, 2002; Zhu et al., 2016). $\mathrm{Pb}$ neurotoxicity causes neurogenerative disorder, neurotransmission impairment and cell signaling deregulation and change in brain morphology because $\mathrm{Pb}$ disturb $\mathrm{Ca}^{2+}$ flux that result in disrupting calcium regulatory functions, thus cell necrosis and oxidative stress occurs (Marchetti, 2003; Verstraeten et al., 2008). Calcium is an important ion for the regulation and release of neurotransmitters. $\mathrm{Pb}$ makes its way into the transport system of calcium by mimicking it, and ultimately enters the nervous system. Calcium homeostasis is disturbed due to $\mathrm{pb}$ accumulation and

[Citation: Ishaque, A., Ishaque, S., Malik, A., Abbas, H.G. (2020). Toxic effects of lead on fish and human. Biol. Clin. Sci. Res. J., 2020: 47. doi: https://doi.org/10.54112/bcsrj.v2020i1.47] 
it effects the mechanisms of neurotransmission (Westerink and Vijverberg, 2002). Brain transcription factors are regulated by zinc finger proteins. When the body is exposed to pb, it replaces zinc ions, which result in neurological injuries tracked by hyperactive movement that cause hyperventilation in fish (Zizza et al., 2013). Cholinesterase is an enzyme responsible for functioning of NS by catabolizing acetylcholine. $\mathrm{Pb}$ inhibits cholinesterase activity by occupying its position that result in the accumulation of Ach which lead to severe neurotoxicity that can be life threatening (Nunes et al., 2014). In fish, lead exposure leads to neurotransmitter changes and synaptic damage which leads to behavioral and neurological problems and it was observed that changes in neurotransmitter systems were directly related to ATP (Senger et al., 2006). Pb toxicity also damage structural and functional conformation of protein, that alter gene expression and disturb DNA repairing process (Richetti et al., 2011). To assess the toxicity caused by $\mathrm{Pb}$ in fish, neurotoxicity can be used as a biomarker for indicating the $\mathrm{Pb}$ interaction to that fish.

\section{Immune response}

In fish $\mathrm{Pb}$ exposure cause alteration in immune response that effect immune functions and cause neurological disorder, physiological and biochemical disturbance (Paul et al., 2014; Small, 2004). Environmental immune toxicant $\mathrm{Pb}$ also disrupt antibody production, hematopoietic and phagocytic activity also reduced (Dunier, 1996). It has been reported by (Adeyemo et al., 2010) that $\mathrm{Pb}$ exposure cause tissue injury in fish, that cause change in the lymphocytes count, Witeska (2005) reported that this decrease is due to stress reaction which induces cortisol secretion that promote apoptosis (Witeska, 2005). $\mathrm{Pb}$ activity also disturbs cytokines expression which is responsible for regulating immune response. In crucian carp (Dai et al., 2018) observed that $\mathrm{Pb}$ cause serious damage to immune system of fish as amplification in mRNA expression of TNF and IL10 was spotted, however both factors are responsible for inflammatory immune action and apoptosis (Dai et al., 2018; Savan and Sakai, 2006). Pb has a toxic effect on fish immune system as it disturbs immune responses i.e. inflammation or apoptosis of leukocytes and lymphocytes, disrupt intracellular transduction signals by inhibiting biomolecules activity. Thus, to determine toxicity in fish disturbed immune response is giving the signal of $\mathrm{Pb}$ exposure in the environment.

\section{Oxidative stress}

Reactive oxygen species (ROS) like superoxide radicals, hydroxyl radicals and hydrogen peroxides are produced in fish due to the induction of oxidative stress when metal gets accumulated in its tissues (Eroglu et al., 2015; Kim and Kang, 2016d; Kim et al., 2017a). A Fenton reaction also occurs due to oxidative stress which converts hydrogen peroxide to hydroxyl radicals which causes nucleic acid and protein damage and lipid peroxidation in fish body (Kim and Kang,2015b, c; Kim et al., 2017a). An imbalance between biological detoxification systems (e.g., antioxidant responses like GST, GSH, CAT and SOD) and free radicals generated causes oxidative stress in fish (Kim and Kang, 2015c; Kim et al., 2017b). Therefore, oxidative stress in metal-exposedfish can be evaluated by checking for their antioxidant responses. Superoxide dismutase (SOD) activity is directly related to the exposure concentration of $\mathrm{Pb}$ i.e. SOD activity decreases as antioxidants production decreases and SOD activity increases as ROS production as a defensive mechanism increases (Alsop et al., 2016; Chen et al., 2014; Kim et al., 2017a). After Pb exposure, Atli and Canli (2007) observed amplified CAT activity in Oreochromis niloticu as a measure to shield the tissue and cell against injury caused by ROS generation.

\section{Conflict of interest}

The authors declared absence of conflict of interest.

\section{References}

Adeyemo, O., Adedeji, O., and Offor, C. (2010). Blood lead level as biomarker of environmental lead pollution in feral and cultured African catfish (Clarias gariepinus). Nigerian veterinary journal $\mathbf{3 1}$.

Al-Balawi, H. F. A., Al-Akel, A. S., Al-Misned, F., Suliman, E. A. M., Al-Ghanim, K. A., Mahboob, S., and Ahmad, Z. (2013). Effects of sub-lethal exposure of lead acetate on histopathology of gills, liver, kidney and muscle and its accumulation in these organs of Clarias gariepinus. Brazilian archives of biology and technology 56, 293-302.

Alsop, R. J., Schober, R. M., and Rheinstädter, M. C. (2016). Swelling of phospholipid membranes by divalent metal ions depends on the location of the ions in the bilayers. Soft Matter 12, 6737-6748.

Alvares, A. P., Fischbein, A., Sassa, S., Anderson, K. E., and Kappas, A. (1976). Lead intoxication: Effects on cytochrome P-450-mediated hepatic oxidations. Clinical Pharmacology \& Therapeutics 19, 183-190.

Alves, L., Glover, C., and Wood, C. (2006). Dietary $\mathrm{Pb}$ accumulation in juvenile freshwater rainbow trout (Oncorhynchus mykiss).

[Citation: Ishaque, A., Ishaque, S., Malik, A., Abbas, H.G. (2020). Toxic effects of lead on fish and human. Biol. Clin. Sci. Res. J., 2020: 47. doi: https://doi.org/10.54112/bcsrj.v2020i1.47] 
Archives of environmental contamination and toxicology 51, 615.

Apostoli, P., Kiss, P., Porru, S., Bonde, J. P., and Vanhoorne, M. (1998). Male reproductive toxicity of lead in animals and humans. ASCLEPIOS Study Group. Occupational and environmental medicine 55, 364-374.

Assennato, G., Paci, C., Baser, M. E., Molinini, R., Candela, R. G., Altamura, B. M., and Giorgino, R. (1987). Sperm count suppression without endocrine dysfunction in lead-exposed men. Archives of Environmental Health: An International Journal 42, 124-127.

Audesirk, G. (1993). Electrophysiology of lead intoxication: effects on voltage-sensitive ion channels. Neurotoxicology 14, 137-147.

Bernard, A., and Lauwerys, R. (1984). Cadmium in human population. Experientia 40, 143-152.

Braunstein, G. D., Dahlgren, J., and Loriaux, D. L. (1978). HYPOGONADISI. f IN CHRONICALLY LEAD-POISONED!·! Etl. Infertility 1, 33-51.

Campara, P., D'andrea, F., Micciolo, R., Savonitto, C., Tansella, M., and Zimmermann-Tansella, C. (1984). Psychological performance of workers with blood-lead concentration below the current threshold limit value. International archives of occupational and environmental health 53, 233-246.

Castro-González, M., and Méndez-Armenta, M. (2008). Heavy metals: Implications associated to fish consumption. Environmental toxicology and pharmacology 26, 263-271.

Chain, E. P. o. C. i. t. F. (2010). Scientific Opinion on lead in food. EFSA Journal 8, 1570.

Chang, L.-F., Jiang, S.-J., and Sahayam, A. (2007). Speciation analysis of mercury and lead in fish samples using liquid chromatographyinductively coupled plasma mass spectrometry. Journal of Chromatography A 1176, 143-148.

Chen, Y., Huang, L., Wu, W., Ruan, Y., Wu, Z., Xue, Z., and Fu, F. (2014). Speciation analysis of lead in marine animals by using capillary electrophoresis couple online with inductively coupled plasma mass spectrometry. Electrophoresis 35, 1346-1352.

Cheng, H., and Hu, Y. (2010). Municipal solid waste (MSW) as a renewable source of energy: Current and future practices in China. Bioresource technology 101, 3816-3824.

Coscia, G., Discalzi, G., and Ponzetti, C. (1987). Immunological aspects of occupational lead exposure. La Medicina del lavoro 78, 360.
Dai, J., Zhang, L., Du, X., Zhang, P., Li, W., Guo, X., and Li, Y. (2018). Effect of lead on antioxidant ability and immune responses of crucian carp. Biological trace element research 186, 546-553.

Dunier, M. (1996). Water pollution and immunosuppression of freshwater fish. Italian Journal of Zoology 63, 303-309.

Dural, M., Göksu, M. Z. L., and Özak, A. A. (2007). Investigation of heavy metal levels in economically important fish species captured from the Tuzla lagoon. Food chemistry 102, 415-421.

Ehrlich, R., Robins, T., Jordaan, E., Miller, S., Mbuli, S., Selby, P., Wynchank, S., Cantrell, A., De Broe, M., and D'Haese, P. (1998). Lead absorption and renal dysfunction in a South African battery factory. Occupational and Environmental medicine 55, 453-460.

Eroglu, A., Dogan, Z., Kanak, E., Atli, G., and Canli, M. (2015). Effects of heavy metals $(\mathrm{Cd}, \mathrm{Cu}$, $\mathrm{Cr}, \mathrm{Pb}, \mathrm{Zn}$ ) on fish glutathione metabolism. Environmental Science and Pollution Research 22, 3229-3237.

Evis, M. J., Dhaliwal, K., Kane, K. A., Moore, M. R., and Parratt, J. R. (1987). The effects of chronic lead treatment and hypertension on the severity of cardiac arrhythmias induced by coronary artery occlusion or by noradrenaline in anaesthetised rats. Archives of toxicology 59, 336-340.

Ewers, U., Stiller-Winkler, R., and Idel, H. (1982). Serum immunoglobulin, complement C3, and salivary IgA levels in lead workers. Environmental research 29, 351-357.

Farkas, A., Salánki, J., and Specziár, A. (2003). Ageand size-specific patterns of heavy metals in the organs of freshwater fish Abramis brama L. populating a low-contaminated site. Water research 37, 959-964.

Flegal, A. R. (1986). Lead in tropical marine systems: a review. Science of the Total Environment 58, 1-8.

Gerhardsson, L., Chettle, D., Englyst, V., Nordberg, G., Nyhlin, H., Scott, M., Todd, A., and Vesterberg, O. (1992). Kidney effects in long term exposed lead smelter workers. Occupational and Environmental Medicine 49, 186-192.

Gidlow, D. A. (2015). Lead toxicity. Occupational medicine 65, 348-356.

Goering, P. (1993). Lead-protein interactions as a basis for lead toxicity. Neurotoxicology 14, 45.

Goyer, R. (1989). Mechanisms of lead and cadmium nephrotoxicity. Toxicology letters 46, 153-162.

[Citation: Ishaque, A., Ishaque, S., Malik, A., Abbas, H.G. (2020). Toxic effects of lead on fish and human. Biol. Clin. Sci. Res. J., 2020: 47. doi: https://doi.org/10.54112/bcsrj.v2020i1.47] 
Grosell, M., Gerdes, R., and Brix, K. (2006). Influence of $\mathrm{Ca}$, humic acid and $\mathrm{pH}$ on lead accumulation and toxicity in the fathead minnow during prolonged water-borne lead exposure. Comparative Biochemistry and Physiology Part C: Toxicology \& Pharmacology 143, 473-483.

Gurer, H., and Ercal, N. (2000). Can antioxidants be beneficial in the treatment of lead poisoning? Free Radical Biology and Medicine 29, 927945.

Hogstedt, C., Hane, M., Agrell, A., and Bodin, L. (1983). Neuropsychological test results and symptoms among workers with well-defined long-term exposure to lead. Occupational and Environmental Medicine 40, 99-105.

Hsu, P.-C., and Guo, Y. L. (2002). Antioxidant nutrients and lead toxicity. Toxicology 180, 33-44.

IARC, W. (2006). IARC monographs on the evaluation of carcinogenic risks to humans: inorganic and organic lead compounds. Vol. 87. World Health Organization, Lyon, France.

Jaishankar, M., Tseten, T., Anbalagan, N., Mathew, B. B., and Beeregowda, K. N. (2014). Toxicity, mechanism and health effects of some heavy metals. Interdisciplinary toxicology 7, 60-72.

Javed, M. (2012). Effects of zinc and lead toxicity on the growth and their bioaccumulation in fish. Pak. Vet. J 32, 357-362.

Kalay, M., Ay, Ö., and Canli, M. (1999). Heavy metal concentrations in fish tissues from the Northeast Mediterranean Sea. Bulletin of environmental contamination and toxicology 63, 673-681.

Khalil-Manesh, F., Gonick, H. C., and Cohen, A. H. (1993). Experimental model of lead nephropathy. III. Continuous low-level lead administration. Archives of Environmental Health: An International Journal 48, 271-278.

Kim, J.-H., and Kang, J.-C. (2014). The selenium accumulation and its effect on growth, and haematological parameters in red sea bream, Pagrus major, exposed to waterborne selenium. Ecotoxicology and environmental safety 104, 96-102.

Kim, J.-H., and Kang, J.-C. (2015a). The arsenic accumulation and its effect on oxidative stress responses in juvenile rockfish, Sebastes schlegelii, exposed to waterborne arsenic (As3+). Environmental Toxicology and Pharmacology 39, 668-676.

Kim, J.-H., and Kang, J.-C. (2015b). The lead accumulation and hematological findings in juvenile rock fish Sebastes schlegelii exposed to the dietary lead (II) concentrations. Ecotoxicology and environmental safety 115, 33-39.

Kim, J.-H., and Kang, J.-C. (2016a). The chromium accumulation and its physiological effects in juvenile rockfish, Sebastes schlegelii, exposed to different levels of dietary chromium (Cr6+) concentrations. Environmental toxicology and pharmacology 41, 152-158.

Kim, J.-H., and Kang, J.-C. (2016b). The immune responses in juvenile rockfish, Sebastes schlegelii for the stress by the exposure to the dietary lead (II). Environmental toxicology and pharmacology 46, 211-216.

Kim, J.-H., and Kang, J.-C. (2016c). The toxic effects on the stress and immune responses in juvenile rockfish, Sebastes schlegelii exposed to hexavalent chromium. Environmental Toxicology and Pharmacology 43, 128-133.

Kim, J.-H., and Kang, J.-C. (2017a). Effects of dietary chromium exposure to rockfish, Sebastes schlegelii are ameliorated by ascorbic acid. Ecotoxicology and environmental safety 139, 109-115.

Kim, J.-H., and Kang, J.-C. (2017b). Effects of subchronic exposure to lead $(\mathrm{Pb})$ and ascorbic acid in juvenile rockfish: antioxidant responses, MT gene expression, and neurotransmitters. Chemosphere 171, 520-527.

Lai, B., Murthy, R., Anand, M., Chandra, S., Kumar, R., Tripathi, O., and Srimal, R. (1991). Cardiotoxicity and hypertension in rats after oral lead exposure. Drug and chemical toxicology 14, 305-318.

Lead, W. I. (1995). Environmental health criteria 165. International Programme on Chemical Safety. Geneva: World Health Organization.

Lee, T.-h., and Jiang, S.-J. (2005). Speciation of lead compounds in fish by capillary electrophoresis-inductively coupled plasma mass spectrometry. Journal of Analytical Atomic Spectrometry 20, 1270-1274.

Lerda, D. (1992). Study of sperm characteristics in persons occupationally exposed to lead. American journal of industrial medicine 22, 567-571.

Loghman-Adham, M. (1997). Renal effects of environmental and occupational lead exposure. Environmental health perspectives 105, 928939.

Mantere, P., Hänninen, H., Hernberg, S., and Luukkonen, R. (1984). A prospective followup study on psychological effects in workers

[Citation: Ishaque, A., Ishaque, S., Malik, A., Abbas, H.G. (2020). Toxic effects of lead on fish and human. Biol. Clin. Sci. Res. J., 2020: 47. doi: https://doi.org/10.54112/bcsrj.v2020i1.47] 
exposed to low levels of lead. Scandinavian journal of work, environment \& health, 43-50.

Marchetti, C. (2003). Molecular targets of lead in brain neurotoxicity. Neurotoxicity research $\mathbf{5}$, 221-235.

Nunes, B., Brandão, F., Sérgio, T., Rodrigues, S., Gonçalves, F., and Correia, A. T. (2014). Effects of environmentally relevant concentrations of metallic compounds on the flatfish Scophthalmus maximus: biomarkers of neurotoxicity, oxidative stress and metabolism. Environmental Science and Pollution Research 21, 7501-7511.

Oflaherty, E. J. (1995). Physiologically based models for bone-seeking elements: V. Lead absorption and disposition in childhood. Toxicology and applied pharmacology 131, 297-308.

Patra, R., Swarup, D., and Dwivedi, S. (2001). Antioxidant effects of $\alpha$ tocopherol, ascorbic acid and L-methionine on lead induced oxidative stress to the liver, kidney and brain in rats. Toxicology 162, 81-88.

Paul, N., Chakraborty, S., and Sengupta, M. (2014). Lead toxicity on non-specific immune mechanisms of freshwater fish Channa punctatus. Aquatic Toxicology 152, 105-112.

Philip, A. T., and Gerson, B. (1994). Lead PoisoningPart II: Effects and Assay. Clinics in laboratory medicine 14, 651-670.

Ponka, P. (1999). Cell biology of heme. The American journal of the medical sciences 318, 241-256.

Richetti, S. K., Rosemberg, D. B., Ventura-Lima, J., Monserrat, J. M., Bogo, M. R., and Bonan, C. D. (2011). Acetylcholinesterase activity and antioxidant capacity of zebrafish brain is altered by heavy metal exposure. Neurotoxicology 32, 116-122.

Rogers, J., Richards, J., and Wood, C. (2003). Ionoregulatory disruption as the acute toxic mechanism for lead in the rainbow trout (Oncorhynchus mykiss). Aquatic toxicology 64, 215-234.

Sakai, T. (2000). Biomarkers of lead exposure. Industrial health 38, 127-142.

Savan, R., and Sakai, M. (2006). Genomics of fish cytokines. Comparative Biochemistry and Physiology Part D: Genomics and Proteomics 1, 89-101.

Senger, M. R., Rico, E. P., de Bem Arizi, M., Frazzon, A. P. G., Dias, R. D., Bogo, M. R., and Bonan, C. D. (2006). Exposure to $\mathrm{Hg} 2+$ and $\mathrm{Pb} 2+$ changes NTPDase and ecto-5'nucleotidase activities in central nervous system of zebrafish (Danio rerio). Toxicology 226, 229-237.

Small, B. C. (2004). Effect of isoeugenol sedation on plasma cortisol, glucose, and lactate dynamics in channel catfish Ictalurus punctatus exposed to three stressors. Aquaculture 238, 469-481.

Somero, G. N., Chow, T. J., Yancey, P. H., and Snyder, C. B. (1977). Lead accumulation rates in tissues of the estuarine teleost fish, Gillichthys mirabilis: salinity and temperature effects. Archives of environmental Contamination and Toxicology 6, 337-348.

Souid, G., Souayed, N., Yaktiti, F., and Maaroufi, K. (2015). Lead accumulation pattern and molecular biomarkers of oxidative stress in seabream (Sparus aurata) under short-term metal treatment. Drug and chemical toxicology 38, 98-105.

Sures, B., Dezfuli, B. S., and Krug, H. F. (2003). The intestinal parasite Pomphorhynchus laevis (Acanthocephala) interferes with the uptake and accumulation of lead $(210 \mathrm{~Pb})$ in its fish host chub (Leuciscus cephalus). International Journal for Parasitology 33, 1617-1622.

Sures, B., and Siddall, R. (1999). Pomphorhynchus laevis: the intestinal acanthocephalan as a lead sink for its fish host, chub (Leuciscus cephalus). Experimental Parasitology 93, 6672 .

Telisman, S., Cvitković, P., Jurasović, J., Pizent, A., Gavella, M., and Rocić, B. (2000). Semen quality and reproductive endocrine function in relation to biomarkers of lead, cadmium, zinc, and copper in men. Environmental health perspectives 108, 45-53.

Verstraeten, S. V., Aimo, L., and Oteiza, P. I. (2008). Aluminium and lead: molecular mechanisms of brain toxicity. Archives of toxicology 82, 789-802.

Vinodhini, R., and Narayanan, M. (2008). Bioaccumulation of heavy metals in organs of fresh water fish Cyprinus carpio (Common carp). International Journal of Environmental Science \& Technology 5, 179-182.

Westerink, R. H., and Vijverberg, H. P. (2002). Vesicular catecholamine release from rat $\mathrm{PC} 12$ cells on acute and subchronic exposure to polychlorinated biphenyls. Toxicology and applied pharmacology 183, 153-159.

Witeska, M. (2005). Stress in fish-hematological and immunological effects of heavy metals. Electronic journal of ichthyology 1, 35-41.

Zhai, Q., Wang, H., Tian, F., Zhao, J., Zhang, H., and Chen, W. (2017). Dietary Lactobacillus plantarum supplementation decreases tissue

[Citation: Ishaque, A., Ishaque, S., Malik, A., Abbas, H.G. (2020). Toxic effects of lead on fish and human. Biol. Clin. Sci. Res. J., 2020: 47. doi: https://doi.org/10.54112/bcsrj.v2020i1.47] 
lead accumulation and alleviates lead toxicity in Nile tilapia (Oreochromis niloticus). Aquaculture Research 48, 5094-5103.

Zhu, B., Wang, Q., Shi, X., Guo, Y., Xu, T., and Zhou, B. (2016). Effect of combined exposure to lead and decabromodiphenyl ether on neurodevelopment of zebrafish larvae. Chemosphere 144, 1646-1654.
Zizza, M., Giusi, G., Crudo, M., Canonaco, M., and Facciolo, R. M. (2013). Lead-induced neurodegenerative events and abnormal behaviors occur via ORXRergic/GABAARergic mechanisms in a marine teleost. Aquatic toxicology 126, 231241.

\section{(c) (7) \&}

Open Access This article is licensed under a Creative Commons Attribution 4.0 International License, which permits use, sharing, adaptation, distribution and reproduction in any medium or format, as long as you give appropriate credit to the original author(s) and the source, provide a link to the Creative Commons licence, and indicate if changes were made. The images or other third party material in this article are included in the article's Creative Commons licence, unless indicated otherwise in a credit line to the material. If material is not included in the article's Creative Commons licence and your intended use is not permitted by statutory regulation or exceeds the permitted use, you will need to obtain permission directly from the copyright holder. To view a copy of this licence, visit http://creativecommons.org/licen ses/by/4.0/.

(C) The Author(s) 2020
[Citation: Ishaque, A., Ishaque, S., Malik, A., Abbas, H.G. (2020). Toxic effects of lead on fish and human. Biol. Clin. Sci. Res. J., 2020: 47. doi: https://doi.org/10.54112/bcsrj.v2020i1.47] 